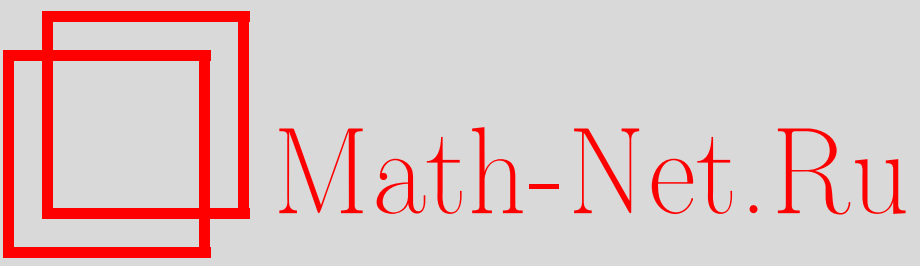

Н. С. Бахвалов, А. Ю. Беляев, М. И. Вишик, В. В. Жиков, В. П. Маслов, О. А. Олейник, Г. П. Панасенко, А. Л. Пятницкий, Сергей Михайлович Козлов (некролог), УМH, 1996, том 51, выпуск 4, 145-146

DOI: https://doi.org/10.4213/rm1562

Использование Общероссийского математического портала Math-Net.Ru подразумевает, что вы прочитали и согласны с пользовательским соглашением http: //www. mathnet.ru/rus/agreement

Параметры загрузки:

IP : 18.207 .199 .55

26 апреля 2023 г., 13:19:51 


\section{СЕРГЕЙ МИХАЙЛОВИЧ КОЗЛОВ}

7 апреля 1995 года на 41 году жизни скончался выдающийся российский математик, профессор университета Прованс (Марсель, Франция) Сергей Михайлович Козлов.

Ушел из жизни ученњй большого таланта и широких научных интересов, человек разносторонний, обладающий яркой индивидуальностью.

К кругу научных интересов С. М. Козлова относятся различные проблемы теории усреднения, теории неупоря доченных систем, уравнения Ито в частных производных и многие другие задачи математической физики и теории стохастических уравнений. Широкую известность ему принесли замечательные результаты об усреднении почти-периодических и случайных операторов. Ему принадлежат фундаментальные исследования по усреднению разностных схем и случайных блужданий на решетках, пионерская работа об усреднении уравнения Фоккера-Планка.

С.М. Козлов родился 17 мая 1954 года в Москве в семье научных работников.

Обладая незаурядными способностями, со школьных лет он проявлял большой интерес к математике.

После окончания школы Сергей Михайлович учился в Московском институте электронного машиностроения, где была организована специальная группа для одаренных студентов, не прошедших по конкурсу в Московский университет. Впоследствии научные и дружеские контакты с однокурсниками, многие из которых стали известными специалистами, не прекращались. Со второго курса С.М. Козлов был переведен на механико-математический факультет МГУ. Учеба в университете происходила под руководством Марка Иосифовича Вишика. Тесную связь со своим учителем Сергей Михайлович поддерживал всю жизнь. Это, а также постоянное участие в работе научных семинаров кафедры дифференциальных уравнений сформировало стиль и круг интересов С.М. Козлова как математика. В 1976 году он окончил механико-математический факультет Московского университета, а в 1979 году досрочно окончил аспирантуру Московского университета, защитив кандидатскую диссертацию "Осреднение дифференциальных операторов со случайными и почти-периодическими коэффициентами".

После окончания аспирантуры С.М. Козлов был направлен на работу в Московский инженерно-строительный институт, где работал до 1992 года на кафедре Прикладной математики, возглавляемой профессором В.В. Кучеренко. Сергей Михайлович был одним из ведущих лекторов и руководителем различных научных семинаров. Он охотно брался за различные прикладные задачи и умел увидеть в них интересные математические проблемы. В 1989 году С. М. Козлов зашитил докторскую диссертацию "Усреднение неупорядоченных структур". В 1991-1992 годах он работал в различных университетах Франции, и с 1993 года он профессор университета Прованс в Марселе.

Еще в студенческие годы С.М. Козлов получил очень интересные результаты для уравнений Ито в частных производных.

С 1977 года Сергей Михайлович увлекается новым в то время направлением - теорией усреднения, и вскоре ему удается построить теорию усреднения эллиптических операторов с квазипериодическими и почти-периодическими коэффициентами.

В 1978-1983 годах С. М. Козловым получен ряд фундаментальных результатов об усреднении операторов со случайными коэффициентами. Разработанный им подход получил широкую известность и используется теперь математиками во всем мире. 
В 1979 году вышла в свет совместная статья С. М. Козлова с В.В. Жиковым и О.А. Олейник и Ха Тьен Нгоаном "Усреднение и $G$-сходимость эллиптических операторов". Эта работа стала важной вехой в развитии теории и послужила отправной точкой для многих дальнейших исследований.

Далее, в 1979-1983 годах последовал большой цикл работ Сергея Михайловича (часть из них совместно с В.В. Жиковым и О.А. Олейник) по усреднению и $G$-сходимости параболических операторов, где были рассмотрены как самые общие вопросы теории $G$-сходимости, так и конкретные классы операторов, такие как операторы со случайными однородными и почти-периодическими коэффициентами.

В 1980 году С.М. Козлов (совместно с В.В. Жиковым и А. Л. Злотником) ввел модельный интегрант, отвечающий "соболевскому пространству с переменным показателем". Впоследствии этот интегрант сыграл ключевую роль в теории эффекта Лаврентьева.

Большой научный интерес представляют развитые С. М. Козловым методы усреднения уравнений с младшими членами. В 1988-1992 годах он исследовал (совместно с А. Л. Пятницким) асимптотическое поведение эффективной диффузии в случае малой молекулярной диффузии.

Важное место в научной биографии Сергея Михайловича занимают фундаментальные результаты об усреднении разностных схем и случайных блужданий на решетках. Частично исследования выполнялись совместно с С. А. Молчановым.

Очень интересны выполненные С. М. Козловым исследования спектра усредняемых операторов и различных спектральных асимптотик. В частности, здесь необходимо упомянуть найденные им многомерные спектральные асимптотики, а также полученные совместно с М.А. Шубиным результаты о совпадении спектров эллиптических случайных операторов.

Ряд исследований С.М. Козлова в 1987-1994 годах относится к изучению проводимости и других эффективных характеристик неупорядоченных структур. В этой бурно развивающейся области строгие математические методы и физические подходы тесно соприкасаются, и вклад Сергея Михайловича высоко оценен как математиками, так и физиками. В этой связи следует отметить его работы по перколяции для сильно неоднородных сред и иерархических (многомасштабных) структур.

Одним из важных для приложений результатов С.М. Козлова является обоснование закона Дарси в пористых средах. Предыдущие исследования в этой области относились к периодическим структурам, в то время как изучение этого вопроса для более реалистичных случайных моделей пористой среды потребовало ряда принципиально новых методов. В настоящее время эта тематика интенсивно исследуется в работах математиков многих стран, и вклад С. М. Козлова во многом определил основные направления ее развития.

Неожиданными и оригинальными оказались выполненные совместно с М. Йором в 1990-1992 годах исследования асимптотик числа оборотов винеровской траектории (так назьваемый винеровский футбол), где даже само определение числа оборотов оказалось нестандартным и основано на новых идеях.

С. М. Козлов активно интересовался теорией усреднения в перфорированном пространстве в связи с приложениями к проблемам диффузии и перколяции. В 1985 году им (совместно с В.В. Жиковым) высказана гипотеза о справедливости теории усреднения при единственном условии связности перфорированного пространства. Спустя несколько лет эта гипотеза была доказана и послужила стимулом для широкого обобщения теории усреднения, в том числе и на фрактальные объекты. Из результатов, полученных С.М. Козловым в последние годы, особого внимания заслуживает усреднение на фракталах. Им была построена модель усреднения и получены явные формулы для неоднородной салфетки Серпинского.

Оригинальное использование методов КАМ теории позволило С. М. Козлову получить очень тонкие результаты об усреднении нелинейных уравнений с почти-периодическими коэффициентами.

Необходимо также отметить исследование асимптотик интегралов Лапласа-Дирихле, исследование асимптотик по малой концентрации примесей и, в частности, уточнение формул Максвелла, а также большое количество явных формул, полученных С.М. Козловым в теории усреднения.

Сергей Михайлович Козлов был человеком разносторонним и очень интересным в общении. Благодаря своему таланту, кипучей энергии и удивительной работоспособности Сергей Михайлович принимал активное участие в исследованиях в самых разнообразных направлениях. Он стал учителем для многих молодых математиков. Светлая память о Сергее Михайловиче сохранится в сердцах всех, кто знал его.

Н. С. Бахвалов, А.Ю. Беляев, М.И. Вишик, В. В. Жиков, В.П. Маслов, О.А. Олейник, Г. П. Панасенко, А. Л. Пятницкий 